\title{
PEMAHAMAN MASYARAKAT DI KECAMATAN LINTAU BUO UTARA TENTANG HUKUM PERKAWINANSEHUBUNGAN DENGAN TERJADINYA PERKAWINAN ANAK
}

\author{
Ashabul Fadhli \\ Universitas Putra Indonesia "YTPK” Padang \\ E-mail: ashabulfadbli@,upizptk.ac.id \\ Ummil Khairiyah \\ Universitas Putra Indonesia "YTPK" Padang \\ E-mail:ummilkhairiyab@upiyptk.ac.id
}

\begin{abstract}
The existence of child marriage practices carried out by the community in Lintan Buo Utara District is believed to originate from the complexity of the chaotic problems, including the lack of public knowledge about marital law. On the findings in the field, the implementation of the marriage carried out by parents or extended family is carried out in two forms, namely marriage conducted at the Batusangkar Religious Court Office after obtaining legal provisions for marriage and marriage dispensation which are not carried out through State law. In the second form of marriage, marriage is usually carried out secretly or under the hand. This finding was confirmed by the narrative and information from the local community which if it was considered as a matter of course. To address the information and habits of the people above, this study seeks to review and deepen people's understanding regarding the extent to which the laws of the State through marital law are implemented. Marriage, or only limited knowledge that is not implemented, and always leads to the habit of marrying children in ways that are contrary to state law.
\end{abstract}

Keywords: Marriage law, fiqh, child marriage, Lintan North Buo

\begin{abstract}
Abstrak
Adanya praktek perkawinan anak yang dilakukan oleh masyarakat di Kecamatan Lintau Buo Utara diyakini bermula dari kompleksitas persoalan yang sembraut, diantaranya adalah lemahnya pengetahuan masyarakat mengenai hukum perkawinan. Pada temuan di lapangan, pelaksanaan pernikahan yang dilansungkan oleh orang tua atau keluarga besar anak dilakukan dalam dua bentuk yaitu perkawinan yang dilakukan di Kantor Pengadilan Agama Batusangkar setelah mendapatkan penetapan hukum dispensasi kawin dan perkawinan yang tidak dilakukan melalui hukum Negara. Pada bentuk perkawinan yang kedua, perkawinan biasanya dilakukan secara diam-diam atau di bawah tangan. Temuan ini dikuatkanoleh penuturan dan informasi dari masyarakat setempat yang sekiranya sudah dianggap sebagai suatu hal yang biasa. Untuk menyikapi informasi dan kebiasaan masyarakat di atas, penelitian ini berusaha untuk mengulas dan mendalami pemahaman masyarakat terkait sejauh mana aturan hukum Negara melalui hukum perkawinan dilaksanakan.Pada akhir penelitian akan diketahui apakah pertimbangan menikahkan anak sudah terintegrasi dengan baik antara ide-ide figh dan isi Undang-Undang Perkawinan, atau hanya sebatas pengetahuan yang tidak dilaksanakan, dan selalu berujung pada kebiasaan menikahkan anak dengan cara-cara yang bertentangan dengan hukum negara.
\end{abstract}

Kata Kunci: Hukum perkawinan, figh, kawin anak, Lintau Buo Utara

\section{Pendahuluan}

Agar dapat melangsungkan perkawinan dengan baik, sejatinya UndangUndang Perkawinan Nomor 1 Tahun 1974 tentang Perkawinan sudah memiliki rumusan hukum tersendiri untuk mengatur tata-tertib

pelaksanaan

pernikahan.Perkawinan yang dipandang baik adalah perkawinan yang sah, yaitu perkawinan yang segala pelaksanaannya merujuk kepada aturan yang telah ditetapkan 
Undang-Undang Perkawinan. Maka, segala bentuk perkawinan yang dilakukan diluar aturan hukum di atas, dapat dikategorikan sebagai perkawinan yang tidak sah dan harus dicegah. Satu diantara bentuk perkawinan yang tidak dibenarkan tersebut adalah perkawinan yang dilakukan pada usia anak, yang dalam hal ini dilakukan dalam wujud yang menyimpang melalui nikah "bawah tangan".

Nikah bawah tangan dianggap tidak sah dikarenakan bentuk perkawinan ini tidak dilansungkan melalui lembaga Negara atau Kantor Urusan Agama (KUA) serta tidak tercatat/dicatatkan (Pasal 2 ayat 2). Dalam prakteknya, di Kecamatan Lintau Buo Utara, nikah bawah tangan diantaranya banyak diakses oleh masyarakat yang menikah pada usia anak, atau pada usia yang tidak dibenarkan Negara, yaitu 19 (sembilan belas) tahun bagi calon pengantin laki-laki dan 16 (enam belas) tahun bagi calon pengantin perempuan (Pasal 7 ayat 1). Adapun perkawinan usia anak yang telah dilakukan melalui jalur dispensasi kawin, meskipun hal itu dibenarkan oleh Negara, namun alasan orang tua untuk menikahkan anaknya tetap harus mendapat perhatian dalam berbagai aspek.

Bagi sejumlah masyarakat di Kecamatan Lintau Buo Utara, perkawinan didefenisikan sebagai sebuah keharusan dan pintu gerbang untuk dibukakankemudahan dalam mengais rezeki. Bagi remaja laki-laki dan perempuan, apabila diketahui sudah bertemu jodoh, dipertemukan jodohnya atau terdapat alasan khusus untuk keharusan dinikahkan maka akan lebih baik untuk segera menikah. Sebab yang terpenting adalah kesiapan menikah, tanpa memandang faktor usia. Untuk dapat melaksanakan perkawinan, beberapa masyarakat masih mengacu pada paradigmafiqhnikahsebagai aturan hukum yang utama,diantaranya tentang anggapan bahwa baligh sebagai indikator bagi anak laki-laki dan anak perempuan sudah boleh menikah. Pemahaman initernyata membuka peluang bagi masyarakat yang lain di Kecamatan Lintau Buo Utara untuk menikahkan anak dengan faktor dan latar belakang sosial yang beragam. Bahkan ditemukan juga alasan orang tua yang menikahkan anaknya dengan dalih ikut-ikutan tetangga.

Oleh sebab itu, tujuan menikah yang menjadi bagian perwujudan dari menghidupkan sunnah, seolah-olah tidak bersentuhandengansyarat-syarat adminstratif yang berlaku ketat melalui hukum negara. Karena memang sejauh ini bentuk pernikahan yang dipraktekkan oleh sejumlah masyarakat di Kecamatan Lintau Buo Utara lebih dipahami sebagai hak pribadi setiap individu. Pengabaian terhadap aturan hukum Negara dalam melaksanakan perkawinan seakan-akan tidak menjadi suatu prilaku hukum yang tercela.

Pemahaman yang tidak sempurna tentang hukum perkawinan di atas, mendorong sejumlah masyarakat di Kecamatan Lintau Buo Utara untuk melansungkan pernikahan berdasarkan pengetahuan seadanya. Setelah diselidiki, kebanyakan masyarakat tidak paham dengan apa yang dimaksud hukum nikah, rukun nikah, teknis pelaksanaan nikah dan batas usia nikah.Padahal, empat aspek tersebut adalah pasal penting sebagai alur peristiwa hukum. Pada beberapa kasuskawin anak yang dinarasikan oleh masyarakat setempat, ketidak pahaman tentang batas usia nikah, penyegeraan perkawinan terjadi pada anak laki-laki dan anak perempuan yang masih berada dibawah usia yang ditetapkanUndang-Undang Perkawinan. Forum pengajian, tradisi dan pengalaman perkawinan anak tetangga yang menikah pada usia muda mengantarkan masyarakat lain untuk mengikuti budaya yang sudah ada. Disamping berawal dari pemahaman 
yang terbatas dalam beragama, sebagian yang lain memiliki alasan yang melekat pada faktor sosial, ekonomi dan budaya.

Denganbegitu,terdapat

anggapanpembenaran bahwa siapapun dan dalam keadaan apapun memiliki hak untuk menikah/dinikahkan. Padahal, sebagaimana yang diinginkan oleh hukum negara, bagi setiap warga negara Indonesia yang akan melansungkan perkawinan, harus memenuhi syarat-syarat perkawinan serta berkewajiban untuk memberitahukan kehendaknya kepada pegawai pencatat pernikahan agar dicatatkan sebagai perkawinan yang sah (Undang-Undang Perkawinan Pasal 2).

Berangkat dari temuan di atas, penelitian ini mencoba menjawab pertanyaan tentang pemahaman masyarakat Kecamatan Lintau Buo Utara dalam memahami hukum perkawinan.Secara garis besar, penelitian ini bertujuan untuk mengungkap bagaimana pemahaman masyarakat Kecamatan Lintau Buo Utara dalam memahami hukum perkawinan yang berdampak pada praktek kawin anak. Penelitian ini penting untuk dilakukan dikarenakan Kecamatan Lintau Buo Utara dikenal memiliki konflik hukum yang signifikan dalam sejumlah kasus di bidang hukum perkawinan, yang diantaranya adalah mengenai angka dispensasi kawin yang didapatkan melalui Kantor Pengadilan Agama Batusangkar berikut dengan keterangan Hakim.Begitu juga dengan keterangan masyarakat tentang adanya kebiasaan menikahkan anak melalui hukum agama saja tanpa keterlibatan Negara. Melalui sumber ini, dapat diketahui bahwa langgengnya kebiasaan menikah muda oleh sejumlah masyarakat di Kecamatan Lintau Buo Utaramerupakan sebuah keniscayaan yang ada.

\section{Metodologi Penelitian}

Penggunaan istilah dari bentuk perkawinan usia anak yang digunakan dalam penelitian ini adalah perkawinan/kawin anak. Perkawinan anak yang dimaksudkan disini yaitu perkawinan yang dilakukan dibawah usia yang ditetapkan oleh UndangUndang Perkawinan dengan faktor pemicunya adalah agama, sosial, ekonomi dan budaya. Keempat faktor tersebut berkelindan pada alasan orang tua menikahkan anaknya.

Penelitian ini menggunakan metode pendekatan yuridis-sosiologis. Pendekatan yuridis sosiologis adalah proses mengidentifikasi dan mengkonsep hukum sebagai istitusi sosial yang riil dan fungsional dalam sistem kehidupan yang nyata.Dalam prosesnya, agar dapat bersentuhan lansung dengan masyarakat, penelitian ini dilakukan dengan cara meneliti ke lapangan untuk memperoleh pengetahuan hukum secara empiris (Soekanto, 2006; Soekanto \& Mamudji, 2001). Pendekatan normatif yang merujuk pada semua regulasi, peraturan atau norma-norma yang terdapat di dalam alQur'an, hadis dan Undang-Undang juga dilakukan dalam penelitian ini, khususnya Undang-Undang Perkawinan Nomor 1 Tahun 1974 tentang Perkawinan.

Untuk memperoleh gambaran tentang pemahaman dan prilaku sosial masyarakat di Kecamatan Lintau Buo Utaramaka digunakan teknik penelitian observasi dan wawancara mendalam. Adapun sumber data sebagai subjek penelitian ini adalah masyarakat di Kecamatan Lintau Buo Utara yang mengetahui atau memiliki kedekatan dengan praktek kawin anak. Dengan demikian, dipahami bahwa subjek penelitian hanya terbatas pada masyarakat yang pernah mengetahui, terlibat atau memiliki kedekatan akses dengan polemik kawin anak. 


\section{Polemik Kawin Anak dalam Undang- Undang Perkawinan}

Kehadiran

Undang-Undang

Perkawinan sebagai hukum Nasional tidak lepas dari semangat untuk melindungi hakhak perempuan Indonesia terutama di bidang perkawinan dan perceraian. Proses kelahiran aturan perkawinan tersebut juga berangkat dari pemikiran-pemikiran fiqh yang kemudian dituangkan dalam butir-butir pasal pada Undang-Undang Perkawinan. Oleh sebab itu, untuk menemukan pemahaman yang baik, maka aturan hukum perkawinan seyogyanya dipahami secara terintegrasi antara ide-ide figh dan UndangUndang Perkawinan. Atau dapat disebut bahwa pemikiran-pemikiran yang bersumber dalam hukum agama telah memiliki ruang tersendiri dalam hukum negara. Pada tataran fiqhmisalnya, perkawinan dipahami sebagai akad yang ditetapkan syara' untuk membolehkan seseorang bersenang-senang antara laki-laki dengan perempuan dan menghalalkan bersenang-senangnya perempuan dengan laki-laki (Wahbah AlZuhaili, 1989:29). Pada Kompilasi Hukum Islam, perkawinan dimaknai sebagai akad yang sangat kuat atau mitsaqan ghaliidŗban untuk menaati perintah Allah dan melaksanakannya merupakan ibadah. Perkawinan bertujuan untuk mewujudkan kehidupan rumah tangga yang sakinah, mawaddah, dan rabmah. Kemudian, jika didalami lebih jauh, pengertian pernikahan di atas tidak beda jauh dengan UdangUndang Perkawinan yang menyebutkan bahwa perkawinan adalah ikatan lahir batin anatara seorang laki-laki dengan seorang perempuan sebagai suami isteri dengan tujuan membentuk keluarga (rumah tangga) yang bahagia dan kekal berdasarkan Ketuhanan Yang Maha Esa.

Atas dasar itu, maka sejatinya perkawinan dapat disebut sebagai peristiwa hukum, yaitu adanya keharusan bagi subyek hukum untuk menjalankan hukum perkawinan yang telah ada sebagaimana mestinya (Pipin Syarifin dan Zarkasy Chumaidy, 1998:72). Untuk dapat melakukan perbuatan hukum pada peristiwa hukum ini, maka subyek hukum dituntut untuk sudah harus dewasa. Sebab dewasa adalah sebuah ukuran yang membolehkan seseorang dibolehkan untuk bertindak hukum, yang dalam hal ini adalah melansungkan perkawinan. Dengan begitu, ketidak dewasaan yang dimiliki oleh seseorang yang berada pada periode anak, menghalangi dirinya untuk bisa melansungkan perkawinan.Merujuk pada referensi fase/usia anak dalam Islam, rupanya terbagi dalam beberapa bagian yang perinciannya dapat ditinjau melalui tema kecakapan hukum (al-Abliyah). Periodesisasi umur dalam kaitannya dengan kecakapan hukum seseorang, membahas seputar kapan seseorang dinyatakan sebagai manusia dewasa. Dalam Islam sendiri dikenal istilah tamyiz, baligh, dan rusyd yang masing-masing memiliki kriteria dan akibat hukum sendirisendiri (Dadan Muttaqien, 2006:1).

Dengan ketentuan bahwa perkawinan dianggap sah apabila dilakukan sesuai dengan kepercayaan dan agama masing-masing (Pasal 2 ayat 1). Untuk memberikan kekuatan hukum terhadap status perkawinan dan melindungi subyek hukum yang terlibat, maka setiap perkawinan harus dicatat menurut perundang-undangan yang berlaku (Pasal 2 ayat 2). Oleh karena itu, segala bentuk perkawinan yang tidak dilansungkan melalui lembaga negara dan tidak dicatatkan tidak dianggap sebagai bentuk perkawinan yang sah. Setiap perkawinan harus dicatatkan melalui Pejabat Pencatatan Nikah (PPN) dan terdaftar di Kantor Urusan Agama (KUA), sehingga pernikahan tersebut mempunyai kekuatan legal formal.Dalam KHI pun juga ditegaskan bahwa turan 
pencatatan ini ssungguhnya bertujuan untuk menjamin ketertiban perkawinan bagi masyarakat yang beragama Islam(Pasal 5 ayat 1).

Guna memberikan perlindungan bagi kehidupan perempuan dan anak di Indonesia, sejatinya negara melalui UndangUndang Perkawinan Nomor 1 Tahun 1974 tentang Perkawinan sudah berupaya sebagai mediator bagi mereka yang memiliki persoalan dengan perkawinan. Salah satu diantaranya adalah segolongan masyarakat yang memiliki kendala dengan syarat dibolehkannya menikah mengenai batas usia nikah. Dalam hal ini, negara hanya akan memberikan jaminan berupa perlindungan hukum bagi mereka yang menikah sesuai dengan syarat-syarat yang telah ditetapkan pada aturan perkawinan. Diantaranya mengenai usia perkawinan yang dianggap sah hanya diberlakukan ketika pihak lakilakitelah mencapai umur 19 tahun dan pihak perempuan telah mencapai umur 16 tahun (Pasal 7 ayat 1).Pada perspektif lain mengenai perlindungan anak, pasal 1 ayat(1) Undang-Undang Nomor. 35 Tahun 2014 Tentang Perlindungan Anak mendefenisikananak sebagai seseorang yang belum berusia 18 (delapan belas) tahun, termasuk anak yang masih dalam kandungan. Undang-Undang ini menganggap bahwa bagi mereka yang berumur kurang dari 18 tahun maka dapat dikategorikan masih tergolong usia anak, yang belum cukup dewasa untuk menikah atau dinikahkan.

Namun, jika terdapat kendala oleh sebagian masyarakat yang berkeinginan atau terdesak untuk menikah/dinikahkan, sementara calon pengantin berada pada usia yang belum dibenarkan dalam UndangUndang Perkawinan, negara telah memberikan kebijakan yang berbeda berupa dispensasi kawin (Pasal 7 ayat 2). Ketentuan ini hanya berlaku bagi mereka yang berkeinginan untuk menikah sementara masih berada pada usia yang belum sempurna. Diterima atau tidak diterimanya perhomonan tersebut tentunya berasal dari pertimbangan hakim setelah melakukan proses hukum terhadap calon pengantin laki-laki, calon pengantin perempuan serta pihak keluarga yang bersangkutan.

Namun terdapat pula anggapan yang berkembang di sebagaian besar masyarakat Indonesia bahwa perkawinan dapat dikatakan sah apabila ketentuan-ketentuan yang disebutkan dalam kitab figh sudah terpenuhi. Artinya, masyarakat meyakini tidak ada kewajiban yang sakral bagi mereka untuk menikah melalui lembaga negara selama telah memenuhi rukun perkawinan sebagaimana yang dijelaskan figh. Pada sebagian masyarakat di Nagara yang lain, juga melakukan bentuk perkawinan itu, bahkan tanpa kehadiran wali, saksi atau qadhi yang pasti (Ashabul Fadhli, 2016:155). Sebab itu, terdapat pandangan tidak perlu lagi adanya pencatatan dari Kantor Urusan Agama dan juga tidak perlu surat nikah.Sebagai akibat dari pemikiran seperti ini, maka banyak timbul perkawinan sirri atau nikah bawah tangan tanpa melibatkan Pegawai Pencatatan Nikah (PPN) sebagai petugas resmi dalam urusan pernikahan (Abdul Manan, 2008:47).

Terkait dengan hal di atas, temuan yang mulanya berangkat dari penetapan hukum yang kemudian dikuatkan oleh pemaparan Hakim Pengadilan Agama Batusangkar diantaranya mengenai perkawinan usia anak. Diketahui bahwa sejumlah masyarakat di di Kecamatan Lintau Buo Utara telah menikahkan anaknya pada usia anak. Menurut Hakim Pengadilan Agama Batusangkar, perkawinan usia anak sudah jamak terjadi di kecamatan tersebut. Untuk dapat melihat secara rinci mengenai persoalan hukumnya, dapat dirujuk pada pada sejumlah penetapan hukum dispensasi 
kawin, begitu juga dengan jumlah permohonan yang masuk. Artinya, kecendrungan untuk terjadinya kawin anak memiliki catatan yang lebih pada kecamatan tersebut. Selain pelaksanaan nikah yang dilakukan melalui dispensasi kawin, kawin bawah tangan juga dipilih oleh orang tua anak sebagai jalan untuk menikahkan anak. Pada temuan lain, paksaan untuk menikahkan anak juga pernah dilakukan oleh orang tua anak terhadap pejabat Negara yang bertugas untuk menikahkan anak.

Pada pernikahan usia anak yang dilakukan oleh masyarakat yang bertempat tinggal jauh dari ibu kota, kebanyakan diantaranya dilakukan oleh masyarakat adat yang masih menjunjung tinggi tradisi dan kebudayaan setempat. Keterbatasan pengetahuan mengenai implmentasi hukum perkawinan menjadi dilema tersendiri untuk mewujudkan masyarakat sadar hukum. Bukan hanya di Kecamatan Lintau Buo Utara, namun hampir di setiap daerah di Indonesia telah ditemukan adanya kebiasaan masyarakat untuk menikah pada usia anak, sebab keputusan tersebut menurut mereka sama sekali tidak bertentangan dengan tradisi dan aturan adat yang dijunjung. Diantara beberapa potret masyarakat adat yang juga diketahui memiliki kebiasaan untuk menikahkan anak pada usia anak diantaranya adalah penelitian Roland Gunawan (2016) dalam tulisannya menyebutkan bahwa dijodohkan karena kasihan -kondisi sosial-ekonomi buruk yang dialami anak-adalah salah satu indikator terjadinya kawin anak di Madura. Anak dinikahkan agar terlepas dan mengurangi beban keluarga. Pada tulisan Iklilah Muzayyanah (2016), indikator kedewasaan seorang anak perempuan Sasak adalah kemampuan menenun kain dan mengolah mutiara hingga mampu menghidupi dirinya sendiri. Atas dasar itu, dalam usia 12-14 tahun anak-anak perempuan telah dewasa dan siap dinikahkan.Berlanjut pada tulisan Santi Devi, P (2012) yang menuturkan bahwa terdapat kawin massal yang dilakukan dua kali dalam setahun yang bertempat di desa Pengotan, Bali. Pada perayaan ini, jumlah pengantin anak relatif lebih banyak dibanding pengantin dewasa.

Sebab itu, perkawinan anak telah diyakini sebagai salah satu permasalahan serius bagi kehidupan perempuan dan anak di Indonesia. Tidak sedikit dari anak-anak di Indonesia, terutama anak yang berjenis kelamin perempuan, dinikahkan atau terpaksa menikah pada usia yang masih sangat muda. Temuan ini secara nasional telah dikuatkan oleh hasil Survey yang dilaksanakan oleh Badan Pusat Statistik (BPS) yang menyajikan tentang polemik kawin anak yang berkaitan dengan pelbagai aspek. Data tersebut juga telah menyajikan daftar daerah di Indonesia yang dapat menjadi prioritas dalam melakukan intervensi untuk mengatasi perkawinan usia anak di Indoenesia. Tidak itu saja, beragam argumen tentang kisruhnya budaya kawin anak juga telah banyak diketengahkan melalui hasil riset dalam berbagai sudut pandang. Hal ini menjadi penanda bahwa diskursus kawin anak memiliki skala dan cakupan masalah yang kompleks, salah satunya dari laporan tentang lebih dari 700 juta anak-anak perempuan di dunia, telah menikah sebelum memasuki usia 15 tahun (UNICEF, 2014:1).Indonesia, merupakan negara ketujuh dengan tingkat perkawinan anak tertinggi di dunia. Satu dari lima perempuan yang berusia 20-24 tahun telah melakukan perkawinan pertama sebelum usia 18 tahun. Survei UNICEF menunjukkan bahwa agama, tradisi, kemiskinan, ketidaksetaraan gender dan ketidakamanan karena konflik merupakan alasan utama tingginya jumlah perkawinan anak. 
Kompleksitas masalah yang dihadirkan akibat adanya kawin anak dapat dipotret menyangkut masalah-masalah seperti hak dan kewajiban anak dalam dunia pendidikan, psikologi anak dalam menjalani peran sebagai seorang istri dalam rumah tangga, dampak melahirkan dini bagi ibu dan bayi yang dilahirkan, gizi buruk, gangguan kesehatan seksual dan reproduksi, pertambahan jumlah penduduk yang tidak terkendali, rantai kemiskinan, penelantaran hingga persoalan-persoalan lain yang lebih serius. Bentuk perkawinan anak juga telah menyumbangkan angka yang serius terhadap angka perceraian, baik yang dilakukan di Kantor Pengadilan Agama ataupun yang dilakukan secara sepihak. Dainataranya dapat ditemukan pada naskah publikasi Novita Kusumaningrum (2015:4) tentang perkawinan di bawah umur dan akibatnya yang dilansir dari putusan perceraian pasangan bawah umur Pengadilan Agama Surakarta dan Pengadilan Agama Karang Anyar; Kemudian pada penelitian Suhadi (2012:170) tentang Pernikahan Dini, Perceraian dan Pernikahan Ulang. Begitu juga dalam bentuk kawin bawah tangan, dimana bentuk perceraian juga dilakukan secara serampangan. Bentuk perceraian kedua ini adalah bentuk perceraian yang banyak ditemui pada polemik kawin anak disebabkan ketika menikah, anak perempuan tidak pernah dinikahkan dan dicatatkan secara sah.

Permasalahan kawin anak tidak hanya mempengaruhi kehidupan anak sebagai pengantin anak dan keluarga anak, namun juga memberikan pengaruh yang sangat kuat terhadap lingkungan sosialnya. Temuan di salah satu jorong di kecamatan Lintau Buo Utara misalnya, dorongan untuk menikahkan anak oleh orang tuanya dikarenakan adanya kebiasaan dari tetangganya yang telah menikahkan anakanak mereka lebih awal sebelum 16 tahun.
Bagi kebanyakan anak perempuan yang menikah lebih awal tersebut, telah mengalami kondisi sosial-ekonomi yang buruk jika dibandingkan dengan anak-anak perempuan lain yang mau menunda usia perkawinan mereka. Pada penelitian yang dilakukan dalam waktu yang lebih panjang, buruknya kualitas kehidupan pengantin anak juga dilanjutkan dan dirasakan oleh anakanak mereka sebagai generasi penerus. Pada catatan BPS yang berbeda, kondisi buruk yang dialami oleh generesi penerus tersebut adalah salah bentuk kemiskinan pada kategori absolout. Kemiskinan secara absolut ditentukan berdasarkan ketidakmampuan untuk mencukupi kebutuhan pokok minimum seperti pangan, sandang, kesehatan, perumahan dan pendidikan yang diperlukan untuk bisa hidup dan bekerja. Kebutuhan pokok minimum diterjemahkan sebagai ukuran finansial dalam bentuk uang. Nilai kebutuhan minimum kebutuhan dasar tersebut dikenal dengan istilah garis kemiskinan (BPS, 2014:7).

Pada temuan lain, keinginan orang tua untuk menikahkan anak tidak jarang dilakukan atas dasar himpitan ekonomi yaitu mengurangi beban ekonomi rumah tangga. Anak lebih baik dinikahkan dengan pertimbangan bahwa anak kedepannya dapat membangun dan menjalankan perekonomiannya sendiri dengan keluarga barunya. Pada konteks ini, anak perempuan adalah subyek yang paling dominan untuk dinikahkan. Dalam keluarga yang masih menganut pemikiran tentang budaya patriarkhi, anak laki-laki lebih utama untuk dipertahankan dirumah dan bersekolah. Berbeda dengan anak perempuan yang dipandang tidak banyak memberikan bantuan ekonomi sebagai pencari nafkah pembantu dalam kehidupan keluarga. 


\section{A. Pandangan Masyarakat di Lintau Buo Utara tentang Hukum Perkawinan}

Untuk mengetahui seberapa besar pemahaman masyarakat di Lintau Buo Utara dalam memahami hukum perkawinan sebagai pedoman dan dasar pelaksanaan pernikahan, maka pada bab ini akan disajikan hasil dari pemahaman tersebut. Sejumlah informan berasal dari tokoh masyarakat, tokoh agama dan masyarakat umum yang memiliki informasi perihal kawin anak atau mengetahui adanya polemik kawin anak di lingkungan mereka.Hasil dari wawancara tersebut dapat dilihat pada tabel berikut ini:

Tabel 1.1 Hukum Nikah

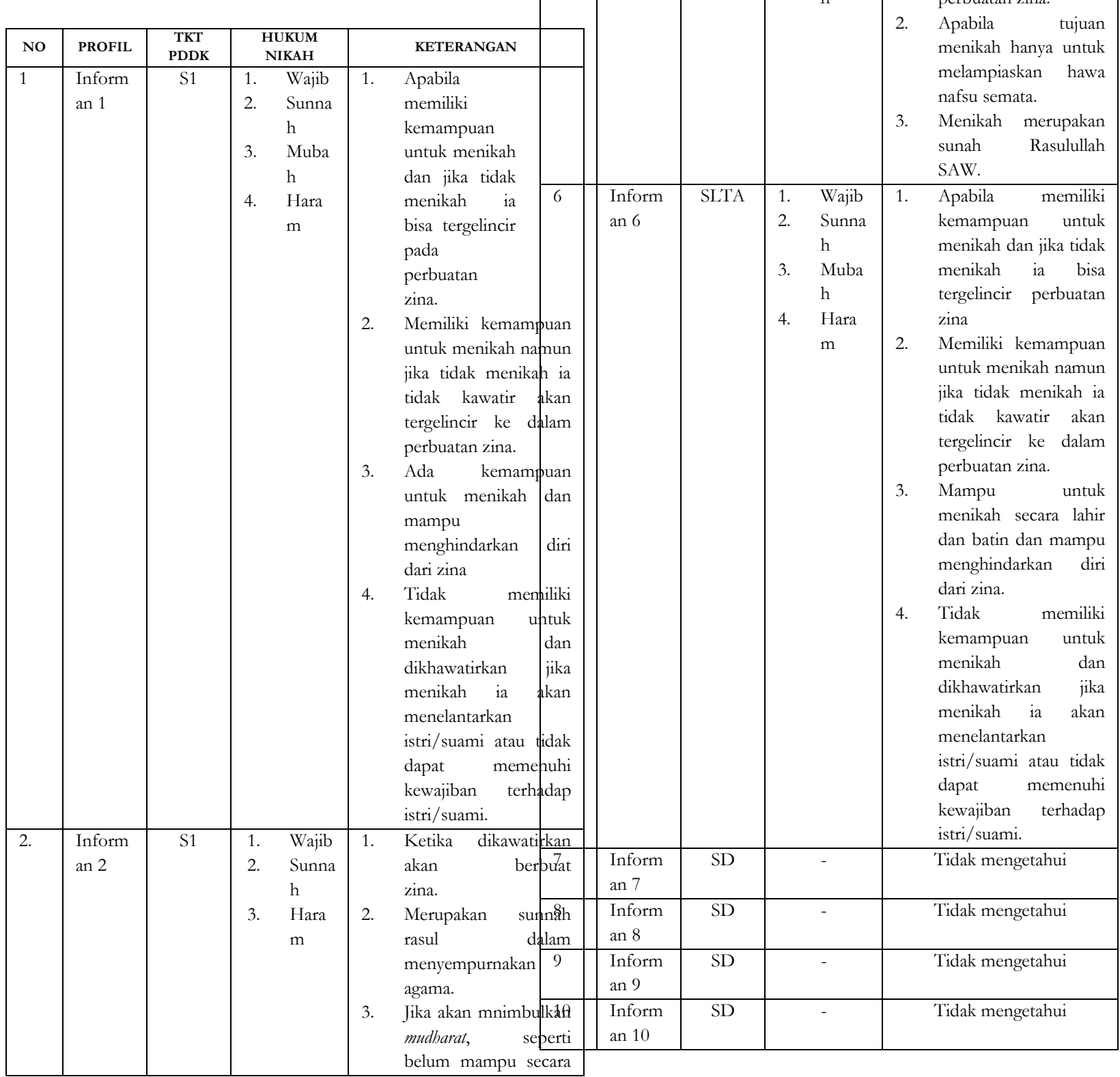
paksakan.

tapi dia

\begin{tabular}{|c|c|c|c|c|c|c|}
\hline & & & & & & $\begin{array}{l}\text { lahir batin tapi dia } \\
\text { paksakan. }\end{array}$ \\
\hline 3 & $\begin{array}{l}\text { Inform } \\
\text { an } 3\end{array}$ & SLTP & & $\begin{array}{l}\text { Wajib } \\
\text { Sunna } \\
h\end{array}$ & 1. & $\begin{array}{lr}\text { Mutlak wajib apabila } \\
\text { ada keinginan dar } \\
\text { kedua belah pihak jika } \\
\text { tidak terdapa } \\
\text { halangan menikah } \\
\text { walaupun } \\
\text { dikawatirkan } \\
\text { terjerumus akan } \\
\text { perbuatan zina. }\end{array}$ \\
\hline
\end{tabular}

2. Menikah adalah sunnah rasul untuk menyempurnaka agama.

Apabila sudah mampu untuk menikah maka dia wajib untuk dinikahkan.

Ada kemampuan untuk menikah secara lahir dan batin dan takut terjerumus pada $\mathrm{m}$ 3. Sunn . 
Dari tabel diatas dapat dapat dilihat bahwa secara teori mengenai hukum menikah masyarakat terbagi menjadi beberapa golongan:

1. Paham

Dikatakan paham karena mereka dapat menjawab pertanyaan peneliti dengan baik dan memaparkan mengenai hukum menikah secara terperinci.

2. Kurang paham

Peneliti menggolongkan pada kategori kurang paham karena informan tidak bisa lansung menjawab pertanyaan, informan meminta waktu selama dua hari untuk mempelajari terlebih dahulu setiap poin pertanyaan yang peneliti ajukan. Mereka menjawab setiap pertanyaan yang peneliti ajukan, namun sering tidak nyambung antara pertanyaan denganjawaban walaupun sudah dikasih waktu dua hari untuk mempelajari materi tersebut.

3. Tidak paham

Mereka yang digolongkan tidak paham karena dari awal percakapan mereka mengakui bahwa mereka tidak ada ilmu tentang pernikahan, karena tidak pernah mempelajari ilmu tersebut.

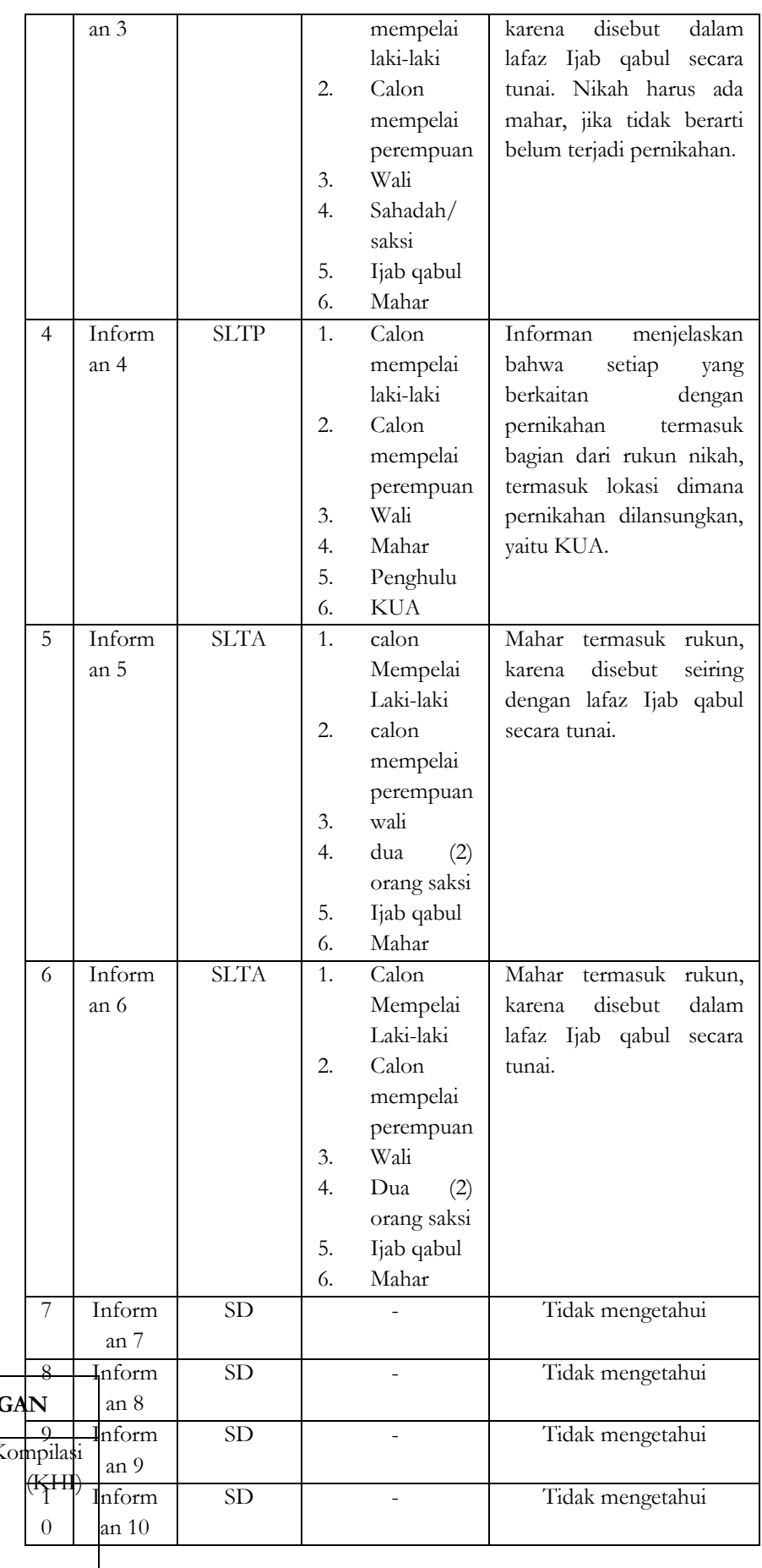

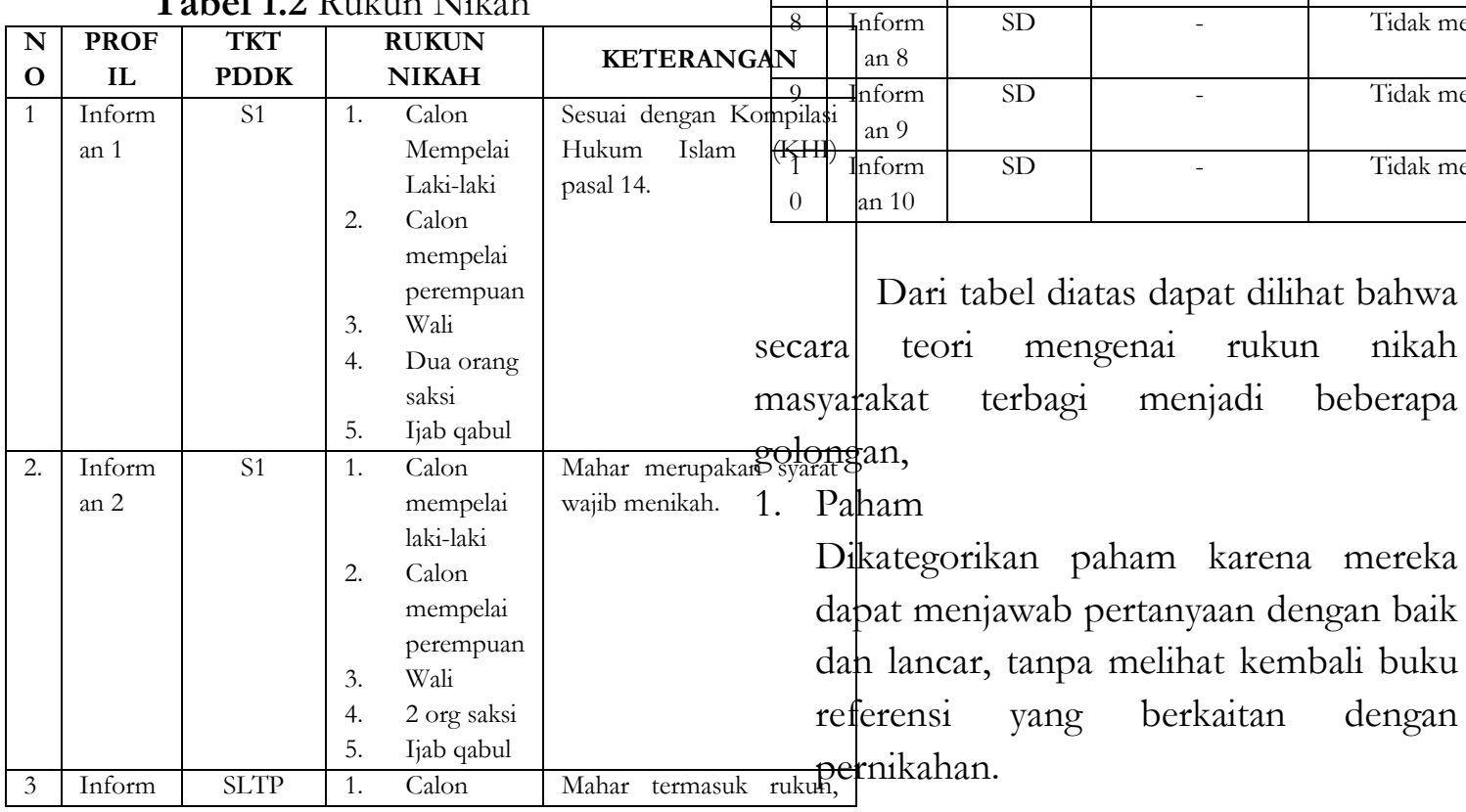


2. Kurang paham

Dikategorikan pada kurang paham karena disaat peneliti melakukan wawancara, mereka terlebih dahulu meminta peneliti untuk menjelaskan terlebih dahulu mengenai pertanyaan yang akan peneliti ajukan dengan alasan dia sudah lama tidak membaca materi tentang pernikahan.

3. Tidak paham

Dikatakan tidak paham karena informan mengakui bahwa dia tidak mengetahui yang sifatnya teori, mereka hanya mengetahui informasi yang terjadi di lapangan. Ia merekomendasikan orang lain untuk diwawancarai yang dia anggap lebih mpaham mengenai pernikahan.

Tabel 1.3 Teknis Pelaksanaan Nikah

\begin{tabular}{|c|c|c|l|l|}
\hline 1 & Informan & SD & $\begin{array}{l}\text { Sesuaikan dengan } \\
\text { syara }\end{array}$ & $\begin{array}{l}\text { Mengikuti Syara' berarti } \\
\text { sudah mengikuti UU } \\
\text { yang dibenarkan oleh } \\
\text { adat. }\end{array}$ \\
\hline
\end{tabular}

Dari tabel diatas dapat dilihat bahwa secara teori mengenai teknis pelaksanaan nikah, masyarakat memiliki kecendrungan yang berbeda dalam memahami aturan dalam syara', adat dan undang-undang,

1. Syara'

Yang memahami bahwa teknis pelaksanaan perkawinan harus sesuai dengan ajaran syara'.Jika sudah dilakukan sesuai dengan syara', maka teknis pelaksanaan sudah dianggap sah secara agama Islam. Kecendrungan terhadap syara' adalah orang yang statusnya ustaz yang lebih paham ilmu fiqh.

\begin{tabular}{|c|c|c|c|c|c|}
\hline $\begin{array}{l}\mathbf{N} \\
\mathbf{O}\end{array}$ & NAMA & $\begin{array}{l}\text { TKT } \\
\text { PDD } \\
\mathbf{K}\end{array}$ & $\begin{array}{c}\text { TEKNIS } \\
\text { PELAKSANAAN }\end{array}$ & $\begin{array}{r}2 . \\
\text { KETERANGAN }\end{array}$ & $\begin{array}{l}\text { Adat } \\
\text { Dalam teknis pelaksanaan perkawinan }\end{array}$ \\
\hline 1 & $\begin{array}{l}\text { Informan } \\
1\end{array}$ & S1 & $\begin{array}{l}\text { Harus sesuai } \\
\text { dengan UU }\end{array}$ & $\begin{array}{l}\text { Dalam UU sudah } \\
\text { mencakup syara?. }\end{array}$ & apabila dilakukan sesuai dengan ya \\
\hline 2 & $\begin{array}{l}\text { Informan } \\
2\end{array}$ & S1 & $\begin{array}{l}\text { Sebaiknya } \\
\text { disesuaikan dengan } \\
\text { undang-undang } \\
\text { perkawinan. }\end{array}$ & $\begin{array}{l}\text { Untuk kemaslahatan, } \\
\text { agar tidak ada } \\
\text { kecurigaan di kemudian } \\
\text { hari. }\end{array}$ & $\begin{array}{l}\text { diatur dalam adat kebiasaan, maka } \\
\text { berarti sudah mencakup semua } \\
\text { pemahaman. Aplikasinya dapat }\end{array}$ \\
\hline 3 & $\begin{array}{l}\text { Informan } \\
3\end{array}$ & $\begin{array}{c}\text { SLT } \\
\text { P }\end{array}$ & $\begin{array}{l}\text { Harus sesuaikan } \\
\text { dengan syara'. }\end{array}$ & $\begin{array}{lr}\text { Utamakan } & \text { ketentuan } \\
\text { syara'dan } & \text { Adat. } \\
\text { Sementara } & \text { Undang- } \\
\text { Undang tidak wajib }\end{array}$ & $\begin{array}{l}\text { ditemukan pada penyelenggaraan } \\
\text { menikah yang ada di Nagari/Jorong. Ini } \\
\text { menyangkut petuahdi Minangkabau }\end{array}$ \\
\hline 4 & $\begin{array}{l}\text { Informan } \\
4\end{array}$ & 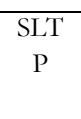 & $\begin{array}{lr}\text { Harus } & \text { sesuai } \\
\text { dengan } & \text { Undang- } \\
\text { Undang. } & \end{array}$ & & $\begin{array}{l}\text { yaitu "adat basandi syara', syara'basan } \\
\text { kitabullab", maksudnya setiap atura }\end{array}$ \\
\hline 5 & $\begin{array}{l}\text { Informan } \\
5\end{array}$ & $\begin{array}{c}\text { SLT } \\
\text { A }\end{array}$ & $\begin{array}{l}\text { Sesuaikan dengan } \\
\text { adat, syarak' dan } \\
\text { Undang-Undang. }\end{array}$ & $\begin{array}{l}\text { Tali tigo sapilin } \text { Satu } \\
\text { kesatuan yang tidak } \\
\text { bisa dipisahkan antara } \\
\text { adat, syarak, dan } \\
\text { Undang- } \\
\text { Undangberbeda secara } \\
\text { teknis namun tidak bुgsa } \\
\text { dipisahkan. }\end{array}$ & $\begin{array}{l}\text { dalam adat bersumber dari ajaran Al } \\
\text { qur'an dan sunnah. Dalam } \\
\text { pelaksanaannya, biasanya dibicarakar } \\
\text { dan dimufakatkan oleh niniak mamak. } \\
\text { Undang-undang }\end{array}$ \\
\hline 6 & $\begin{array}{l}\text { Informan } \\
6\end{array}$ & $\begin{array}{c}\text { SLT } \\
\text { A }\end{array}$ & $\begin{array}{l}\text { Sesuaikan dengan } \\
\text { adat, syarak' dan } \\
\text { undang-undang. }\end{array}$ & $\begin{array}{l}\text { Tali tigo sapilin Satu } \\
\text { kesatuan yang tidak } \\
\text { bisa dipisahkan, } \\
\text { meskipun secara agama } \\
\text { tidak diwajibkan agar } \\
\text { sesuai dengan adat dan } \\
\text { Undang-Undang. }\end{array}$ & $\begin{array}{l}\text { Bahwa terkait teknis pelaksanaar } \\
\text { perkawinan dalam masyarakat yan } \\
\text { hidup bernegara maka harus sesua } \\
\text { dengan yang diatur dalam Undang } \\
\text { undang perkawinan yaitu menikah }\end{array}$ \\
\hline 7 & $\begin{array}{c}\text { Informan } \\
7\end{array}$ & SD & & Tidak mengetahui & lembaga negara yang bernama Kant \\
\hline 8 & $\begin{array}{l}\text { Informan } \\
8\end{array}$ & SD & & Tidak mengetahui & $\begin{array}{l}\text { Urusan Agama (KUA). Menikah } \\
\text { KUA bertujuan supava pernikahan va }\end{array}$ \\
\hline 9 & $\begin{array}{l}\text { Informan } \\
9\end{array}$ & SD & & Tidak mengetahui & dilakukan tercatat dalam dokum \\
\hline
\end{tabular}


negara yang bisa dipertanggung jawabkan apabila ada masalah dikemudian hari. Adapun kelompok yang cendrung memakai UndangUndang adalah dari akademisi.

Tabel 1.4 Batas Usia Nikah

\begin{tabular}{|c|c|c|c|c|}
\hline \multirow{2}{*}{$\begin{array}{l}\mathbf{N} \\
\mathbf{O}\end{array}$} & \multirow[t]{2}{*}{ NAMA } & \multirow{2}{*}{$\begin{array}{c}\text { TKT } \\
\text { PDDK }\end{array}$} & \multicolumn{2}{|c|}{$\begin{array}{c}\text { BATAS } \\
\text { USIA } \\
\text { PERNIKA } \\
\text { H }\end{array}$} \\
\hline & & & $\begin{array}{l}\mathrm{LK} \\
\text { (th) }\end{array}$ & $\begin{array}{l}\text { PR } \\
\text { (th } \\
\text { ) }\end{array}$ \\
\hline 1 & $\begin{array}{l}\text { Informan } \\
1\end{array}$ & SI & 19 & 16 \\
\hline 2 & $\begin{array}{l}\text { Informan } \\
2\end{array}$ & SI & 19 & 17 \\
\hline 3 & $\begin{array}{l}\text { Informan } \\
3\end{array}$ & SLTP & $\begin{array}{l}\text { Balig } \\
\mathrm{h}\end{array}$ & 14 \\
\hline 4 & $\begin{array}{c}\text { Informan } \\
4 \\
\end{array}$ & SLTP & 19 & 17 \\
\hline 5 & $\begin{array}{c}\text { Informan } \\
5\end{array}$ & SLTA & 25 & 20 \\
\hline 6 & $\begin{array}{c}\text { Informan } \\
6\end{array}$ & SLTA & 25 & 18 \\
\hline 7 & $\begin{array}{c}\text { Informan } \\
7\end{array}$ & SD & - & - \\
\hline 8 & $\begin{array}{c}\text { Informan } \\
8\end{array}$ & SD & - & - \\
\hline 9 & $\begin{array}{c}\text { Informan } \\
9\end{array}$ & SD & - & - \\
\hline 10 & $\begin{array}{c}\text { Informan } \\
10\end{array}$ & SD & 18 & 18 \\
\hline
\end{tabular}

Berdasarkan tabel diatas secara keseluruhan dapat disimpulkan bahwa pengetahuan informan secara teori berbedabeda. Tingkat variasi pengetahuan informan terlihat dari latar belakang pendidikan dan statusnya dalam masyarakat. Semakin tinggi pendidikan seseorang, maka semakin luas pengetahuannya. Secara status dapat dipahami bahwa informan yang berstatus sebagai tokoh masyarakat, maka ia akan lebih cendrung dengan hukum adat, begitu juga dengan informan yang dikenal sebagai seorang tokoh agama, maka ia akan lebih cendrung pada ilmu fiqh. Adapun dari golongan masyarakat tersebut yang dikenal sebagai akdemisi, lebih cendrung memakai Undang-Undang yang berlaku, tanpa menafikan ajaran agama dan adat.

\section{Ulasan Pemahaman Masyarakat Sehubungan dengan Terjadinya Kawin Anak}

Sebagai bagian dari masyarakat yang menganut tradisi Minangkabau, masyarakat di Kecamatan Lintau Buo Utara yang berada di Luhak Tanah Datar dikenal sebagai masyarakat yang teguh dalam menjalankan dan melestarikan budaya. Dalam KETERANGANenjalahkan hidup sehari-hari, adat yang melekat pada diri senantiasa dimaknai denganaga manifestasi dari cara berdiri, duduk, berialan
ada batas makan, minum dan sebagainya, ada batas dilihat apakah dia sudah balioh. Minangkabau tidak hanya mengatur sopansantun saja, diantara yang lain juga berisi dewasa ketika hurfentang landasan berfikir, nilai, norma, $\underset{\text { perempuan }}{\text { falsafah }}$ hidup serta aturan-aturan lain yang miestal 7 dipenuhi. Secara prinsip, adat Minangkabau merupakan sebuah konsep kehidupan yang sudah disiapkan oleh nenek moyang orang Minangkabau untuk anak cucunya yang bertujuan untuk mencapai

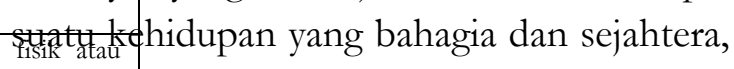
thbjilk dalam kehidupan dunia maupun akhirat (Widia Fithri, 2013:80).

Sekiranya, ide yang dicita-citakan oleh nenek moyang orang Minangkabau sangat sejalan dengan defenisi perkawinan yang diulas dalam pasal 1 Undang-Undang Perkawinan. Begitu pula yang diinginkan oleh Kompilasi Hukum Islam (KHI)yaitu untuk mewujudkan kehidupan rumah tangga yang sakinah, mawaddah dan rahmah.Dalam hal ini, sakinah adalah suasana damai yang melingkupi rumah tangga yang bersangkutan, masing-masing pihak menjalankan perintah Allah SWT dengan saling menghormati dan saling toleransi, sehingga dari suasana sakinah tersebut akan timbul rasa saling mengasihi dan menyayangi (mawaddah), sehingga rasa tanggung jawab kedua belah pihak semakin tinggi (Said Agil Husin al-Munawwar, 
2003:62-63).Artinya, tujuan perkawinan yang diinginkan oleh Undang-Undang Perkawinan dan KHI sudah sangat sejalan dengan prinsip dasar masyarakat Minangkabau.

Meskipun sudah ditemukan titik kesamaan yang dapat menggiring masyarakat di Kecamatan Lintau Buo Utara untuk menikah seseuai aturan dalam hukum perkawinan, namun pada pelaksanaannya tidak terlihat seperti itu. Beberapa diantara masyarakat yang telah diketahui melakukan perkawinan dalam bentuk-bentuk lain selain yang dibenarkan oleh negara seperti tidak melaksanakan pernikahan di lembaga Negara, mengenyampingkan rukun nikah dalam bentuk nikah bawah tangan serta tidak mengindahkan salah satu syarat perkawinan mengenai batas usia.Dengan demikian, pilihan yang dijalankan oleh orang tua untuk menikahkan anak mereka mengindikasikan bahwa dalam segi hukum perkawinan, sejumlah orang tua serta orangorang yang terlibat atau mendiamkan terjadinya kawin anak, dicurigai tidak memiliki pengetahuan yang baik mengenai pelaksanaan pernikahan.

Melalui wawancara mendalam tentang pandangan masyarakat di Kecamatan Lintau Buo Utara tentang hukum perkawinan yang telah diulas sebelumnya, kecurigaan tersebut kemudian dapat terjawab. Pada proses wawancara yang melibatkan sepuluh informan yang memiliki kedekatan atau pengetahuan tentang adanya praktek kawin anak, dapat diketahui adanya persoalan yang signifikan dalam memahami hukum nikah, rukun nikah, teknis pelaksanaan nikah dan batas usia nikah. Hampir seluruh informan yang diwawancarai tidak memahami dengan benar bahkan ada juga yang tidak mengetahui seluruh pertanyaan yang ditanyakan. Jika melihat ulang pada temuan praktek kawin anak yang dilakukan oleh beberapa masyarakat yang bersumber dari penetapan hukum Pengadilan Agama Batusangkar, sekiranya akan ditemukan hubungan yang kuat antara tingkat pengetahuan dan praktek kawin anak.

Pada materi pertanyaan tentang hukum nikah dan pendefenisiannya, setiap informan memiliki jawaban yang berbedabeda satu sama lain. Secara keseluruhan, enam dari sepuluh informan menjawab berupa wajib, sunnah, mubah dan haram. Sementara empat orang yang lain tidak mampu untuk memberikan jawaban apapun. Adapun terkait hukum dasar menikah, hanya dua orang yang menjawab benar, selebihnya menjawab wajib, sunnah dan haram. Selanjutnya, ketika setiap informan ditanyakan mengenai alasan penyebutan hukum nikah, enam dari sepuluh orang informan yang mampu menjawab sebagaimana di atas, dapat menjelaskan argumennya masing-masing meskipun membutuhkan waktu yang relatif lama untuk berfikir.

Meskipun tidak ditemui pasal khusus di dalam Undang-Undang perkawinan, namun hukum menikah merupakan bagian penting untuk menentukan status hukum suatu aturan hukum. Dalam kajian fiqh, tuntutan hukum yang ditujukan kepada subyek hukum (mukallaf) untuk mengerjakan atau meninggalkan sesuatu, atau memilih antara keduanya disebut dengan hukum taklifi. Hukum taklifi berisi tentang suatu perintah dari pembuat hukum (hakim), sasaran ditujukannya hukum (mabkum 'alaih) yaitu mukallaf dan terakhir adalah tuntutan yang berisi perbuatan yang harus dilakukan berupa mengerjakan, meninggalkan atau memilih antara keduanya (Abdul Rahman Dahlan, 2010:49).

Merujuk pada salah satu hadis Abdullah bin Mas'ud RA, ia berkata: 


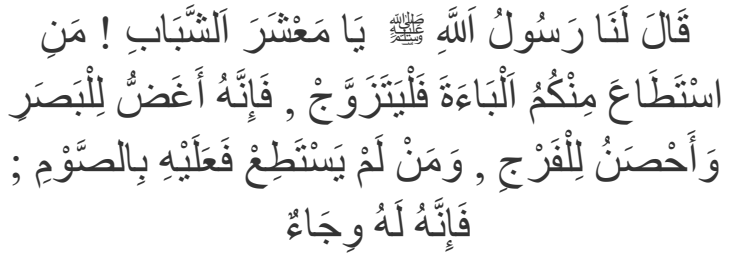

Rasulullah SAW bersabda pada kami; Wahai generasi muda, barangsiapa di antara kamu yang telah mempunyai kemampuan (secara fisik dan harta), hendaknya ia menikah, karena ia dapat menundukkan pandangan dan memelihara kemaluan. Barangsiapa belum mampu hendaklah berpuasa, sebab ia dapat meredam (syahwat). HR. Bukhari dan Muslim

Hadis populer tentang anjuran menikah di atas dapat dijadikan sebagai landasan yang membolehkan laki-laki dan perempuan untuk melakukan sesuatu yang sebelumnya tidak dibolehkan. Karena itu, dapat ditarik kesimpulan bahwa hukum asal dari perkawinan dalam konteks ini adalah boleh atau mubah. Namun dengan melihat kepada sifatnya sebagai sunnah Rasulullah SAW, tentu tidak mungkin dikatakan bahwa hukum asal perkawinan itu hanyalahmubah saja. Mayoritas ulamafiqbberpendapat bahwa pada dasarnya hukum perkawinan yang disepakati adalah sunnah, sebagaimana yang disepakati oleh golongan Zhahiriyah. Berbeda dengan ulama Malikiyah berpendapat bahwa hukum nikah adalah wajib bagi sebagian orang, sunnah untuk sebagian yang laindan mubah untuk segolongan yang lain. Al-Jaziry menguatkan bahwa hukum tersebut diterapkan sesuai dengan keadaan orang yang melakukan perkawinan, artinya berlaku untuk hukum yang lima. Sedangkan bagi masyarakat di Indonesia, hukum mubah dijadikan sebagai pandangan atau hukum dasar awal melakukan pernikahan. Keadaan tersebut diantaranya banyak dipengaruhi pendapat ulama Imam Syafi'i atau Syafi'iyah sebagai salah satu mazhab yang banyak diikuti pemahama fiqh-nya oleh masyarakat Indonesia (Abdul Rahman Ghozali, 2003:17).

Meskipun telah diketahui bahwa nikah memiliki hukum asal mubah, namun hukum tersebut dapat saja berubah menurut abkam al-khamsah seiring adanya perubahan keadaan berupawajib, sunnah, haram, makruh dan mubah (Abdul Rahman Ghozali, 2003:22).Melalui keterangan tersebut, dapat diketahui bahwa semua informan yang didalami keterangannya tidak mengerti dan memahami perihal rukun nikah.

Berlanjut pada materi pertanyaan tentang rukun nikah. Rukun nikah adalah perkara yang menyebabkan sah atau tidaknya suatu pernikahan. Dengan demikian rukun pernikahan itu wajib terpenuhi ketika diadakan akad pernikahan, sebab tidak sah akadnya jika tidak terpenuhi rukunnya (Moh. Anwar, 1971:25). Pada proses wawancara, informan yang mampu menjawab pertanyaan hanya berjumlah enam orang saja, sedangkan empat informan lainnya tidak menjawab apapun. Jika dilihat pada segi jawaban yang diberikan informan, setiap informan menyajikan jawaban yang berbeda-beda, dengan menambahkan atau mengurangi muatan lain dari rukun nikah yang sebenarnya. Secara keseluruhan, informan menjawab berupa calon mempelai laki-laki, calon mempelai perempuan, wali, dua orang saksi, ijab qabul, mahar penghulu dan KUA. Padahal jika dirujuk pada aturan yang dijelas KHI pasal 14 tentang rukun dan syarat perkawinan maka akan didapati bahwa bagi seseorang yang hendak menikah maka harus ada (1) calon suami, (2) calon istri, (3) wali nikah, (4) dua orang saksi, (5) ijab dan kabul.Ketentuan rukun nikah ini juga sudah disepakati oleh jumhur ulama (Amir Syarifuddin, 2007:60-61). 
Terkait mahar sebagai salah satu pemberian yang wajib diberikan oleh suami kepada istri, oleh empat orang dari enam orang informan yang mampu menjawab, menambahkan mahar sebagai bagian dari rukun nikah. Sedangkan yang lain menambahkan penghulu dan KUA. Dengan begitu, dari kesepuluh informan hanya dua orang saja yang menjawab benar.

Kemudian pada pertanyaan tentang teknis pelaksanaan nikah, hanya tujuh dari sepuluh informan yang menjawab. Setiap informan rupanya juga memiliki argumen yang berbeda-beda pada jawabannya. Diantaranya adalah peraturan yang sudah ada di adat, agama dan Undang-Undang harus dijalankan sebagai suatu kesatuan yang tidak boleh dipisahkan. Berbeda dengan pemahaman informan lain bahwa malaksanakan pernikahan melalui hukum agama berarti sudah malaksanakan aturan Negara.Artinya, mendahulukan hukum agama menjadi sebuah keharusan disamping adanya peraturan yang telah ditetapkan Negara dengan mencatatkan setiap perkawinan di KUA.

Pencatatan nikah merupakan kegiatan pencatatan yang dilakukan oleh pejabat Negara yang dalam hal ini adalah pegawai KUA terhadap setiap perkawinan yang berlansung. Aturan hukum ini diantaranya termaktub dalam UndangUndang Perkawinan pasal 2, Kompilasi Hukum Islam pasal 5 sesuai dengan Undang-Undang Nomor 22 tahun 1946 jo Undang-Undang Nomor 32 tahun 1954 tentang pencatatan nikah, talak dan rujuk.

Realitanya, pemikiran informan di atas juga banyak terdengar dari penuturan lain ketika ditanyakan tentang persoalan teknis pernikahan yang dilaksanakan di KUA sebagai lembaga Negara. Hal ini didorong diantaranya oleh berbedanya pemahaman fiqh tentang pelaksanaan nikah yang tidak menyebutkan adanya pelibatan
Negara yaitu Undang-Undang Perkawinan. Argument ini kemudian melahirkan dualisme pemahaman dan konsekuensi hukum yang masing-masingnya berbeda. Bagi Negara, perkawinan harus dicatatkan sementara fightidak berkata demikian. Pada pemahaman yang yang kedua, sebagian besarnya berdampak pada perkawinan secara sembunyi-sembunyiatau nikah bawah tangan yang cendrung berbentuk liar. Namun hal ini rupanya tidak banyak dipahami oleh masyarakat di Kecamatan Lintau Buo Utara yang pernah atau mengetahui adanya kawin anak.

Padahal, jika merujuk pada sumber kemaslahatan atau yang dikenal dengan mashlahah sebagaimana yang diulas oleh alSyathibi bahwaaturan hukum memilikitujuan untuk memelihara tujuan syarak yaitu mendatangkan kemaslahatan dan menolak kemudaratan bagi umat manusia. Selama aturan hukum yang ada tidak bertentangan tujuan pemberlakuan hukum Islam (maqasyid al-syari'ab) dan bersifat rasional, dengan maksud dapat diterima dan menghilangkan kesulitan, maka sejatinya implementasi hukum tersebut boleh diterapkan (alSyathibi, t.th : 172-173).Dalam hal ini, apabila anjuran menikah di lembaga Negara diyakini dapat mendatangkan kemaslahatan, maka sudah seharusnya aturan hukum itu dijaga dan direalisasikan.

Meskipun begitu, setiap informan tetap menyadari bahwa KUA adalah lembaga Negara yang berwenang dalam hal perkawinan danmenjadi suatu keharusan. Hanya saja masih terdapat keraguan dalam memilah dan mengutamakan untuk menikah di lembaga Negara atau tidak.

Apabila pada pertanyaan-pertanyaan sebelumnya sebagian informan bisa memberikan ulasan atas jawaban, namun pada pertanyaan tentang batas usai nikah didapati hampir seluruh informan tidak bisa menjawab dengan benar. Hanya satu orang 
dari sepuluh informan yang bisa menjawab dengan dengan baik. Secara garis besar, jawaban yang diberikan cukup beragam diantaranya adalah menjawab dalam bentuk angka-18, 19, 25 tahun bagi laki-laki dan 14, 16, 17, 18, 20 tahun bagi perempuandan satu diantaranya menjawab dengan periode baligh. Jawaban itupun tidak diberikan dengan kepastian dari pengetahuan yang dimiliki informan, akan tetapi jawaban yang diberikan dalam keadaan ragu dan mereka-reka. Bahkan, dari pendalaman terhadap informan, meskipun telah memberikan jawaban mengenai batas usia dalam bentuk angka, namun pada dasarnya informan tidak menyetujui adanya batas usia nikah ditetapkan Negara sebagai syarat nikah.

Keharusan untuk mengikuti acuan batas usia nikah dalam perkawinan dirujuk pada Undang Undang Perkawinan pasal 7 ayat (1) yaitu pernikahan yang sah secara hukum jika pihak laki-laki sudah mencapai umur 19 tahun dan pihak perempuan mencapai umur 16 tahun.Ini sejalan dengan prinsip yang diletakkan Undang-Undang Perkawinan bahwa calon suami istri harus telah masak jiwa dan raganya agar dapat mewujudkan tujuan perkawinan secara baik.

Berbeda dengan yang ditemui dalam kajianfiqh, bahwa secara tegas tidak didapati aturan fiqhyang memuat tentang batas usia seorang laki-laki atau perempuan agar dapat dikatakan boleh untuk melansungkan perkawinan. Diantaranya yaitu yang dijabarkan dalam tafsir al-Ahkam tentang surat al-Nisa'(4):6 mengenai indikator kapan seorang anak disebut telah memasuki usia baligh (بلغ النكاح). Ulama bersepakat bahwa ketika anak sudah bermimpi yang kumudian junub atau keluar mani. Sedangkan bagi perempuan yaitu ketika telah hamil atau memasuki masa haidh (Muhammad Ali alShabuni, 1999:153).
Argumen kedua yang disajikan melalui paradigm fiqh, merupakan pemahaman yang dianut dan diterima informan untuk bertindak hukum.Menurut kajian ulama terdahulu, baligh dalam fikih tidak bersifat tunggal dan tidak pula bisa disamakan penerapannya (abliyah) pada seluruh aspek muamalah. Dalam beberapa referensi, abliyah seringkali diterjemahkan dengan kapasitas hukum para pihak dalam melakukan perbuatan hukum. Ahliyah dapat bersifat pasif dan dapat pula bersifat aktif. Kepemilikan pada sifat pasif atau istilah lainnya sering disebut juga dengan legal personality dan legal capacity (Muhammad Thahir, 2003:51). Sifat pasif yaitu sebagai pihak yang hanya menerima apa yang telah ditetapkan oleh pihak lain akan haknya seperti hak waris bagi anak dalam kandungan; atau pun hak-hak bagi anak kecil, orang gila, safih dan lainnya (Abliyah al-naqishah). Sedangkan sifat aktif dipahami sebagai kewenangan bagi para pihak untuk dapat bertindak atas/untuk kepentinganya sendiri tanpa harus melibatkan orang lain (Abliyah al-kamilah), yang dalam hal ini salah satunya adalah perkawinan. Untuk itu, apabila seseorang tersebut hendak bertindak hukum selaku orang yang melakukan akad (akid),maka disayaratkan baginya dengan beberapa ketentuan berupa dewasa, sehat mental dan mandiri dari segala hal.

\section{Kesimpulan}

Pertanyaan

mengenai pemahamanmasyarakat terhadap aturan perkawinan yang saling berkelindandengan faktor lain sebagai pendorong terjadinya kawin anak di Kecamatan Lintau Buo Utara, menjadi sesuatu yang penting untuk digali kebenarannya. Berdasarkan pendalaman yang dilakukan dari sepuluh orang informan yang mengetahui atau memiliki kedekatan dengan praktik kawin anak, diketahui bahwa setiap mereka memiliki pemahaman yang 
beragam dalam memberikan ulasan terhadap masing-masing aspek pada materi pertanyaan. Secara keseluruhan dari pertanyaan yang diberikan, dua orang dari sepuluh orang informan paham dengan aturan perkawinan. Artinya, delapan orang informan yang tidak mampu untuk menjawab seluruh pertanyaan secara lugas dan sempurna, mengindikasikan mereka tidak paham dengan pertanyaan yang dimaksud. Pada sesi pertanyaan tentang rukun nikah misalnya, delapan orang dari sepuluh orang informan tidak mampu menjawab dengan benar. Mereka mengakui bahwa selama ini mengetahui rukun nikah dan aturan nikah yang lain berdasarkan apa yang terdengar di lingkungan masyarakat saja.Begitu juga tentang pertanyaan batas usia nikah. Meskipun kebanyakan informan sudah memberikan jawaban dengan bentuk angka, namun pada secara esensial mereka tidak mau bersepakat bahwa ada pembatasan usia tertentu. Dengan pertimbangan bahwa konsep figh mengenai usia baligh lebih dianggap rasional dan mudah untuk dipahami.

Oleh sebab itu, dari sekian faktor yang ada, melalui penelitian ini diyakinibahwa masyarakat yang memiliki kedekatan dengan terjadinya perkawinan anak sebagaimana di atas, tidak memiliki pemahaman yang baik mengenai hukum perkawinan. Asumsi ini dapat dibuktikan melalui ketidakmampuan informan untuk menjawab dan mengulas dengan baik perihal hukum nikah, rukun nikah, teknis pelaksanaan nikah dan batas usia nikah. Dengan begitu, praktek kawin anak dianggap sebagai suatu hal yang biasa saja oleh masyarakat di Kecamatan Lintau Buo menjadi dapat dimengerti, disebabkan kurangnya pengetahuan mereka tentang pelaksanaan pernikahan yang benar dan sah secara hukum.

\section{Daftar Pustaka}

Abdul Manan, Aneka Masalab Hukum Perdata di Indonesia, Jakarta: Kencana, 2008

Abdul Rahman Dahlan, Ushul Fiqh, Jakarta: Amzah, 2010

Abdul Rahman Ghozali, 2003, Fiqh Munakahat, Jakarta: Kencana

Al-Syathibi. T.th. Al-Muwafaqat fi Ushuli al Syariah, Mesir: al-Maktabah alTijariyah

Ashabul Fadhli, 2006, Intervensi Tuanku Terkait Praktek Nikah Sirri di Nagari Kurai Taji Pariaman, Kafa'ah: Jurnal Ilmiah Kajian Gender, Vol.VI No.2 Tahun 2016

Badan Pusat Statistik, 2014, Penghitungan dan Analisis Kemiskinan Makro di Indonesia 2014, BPS: Jakarta

Dadan Muttaqien, Cakap Hukum: Bidang Perkawinan dan Perjanjian Yogyakarta: Insania Cita Press

Moh. Anwar, Fiqh Islam Muamalah, Munakahat, Faraid, dan Jinayah (Hukum Perdata dan Pidana Islam) Beserta Kaidah-kaidah Hukumnya, Bandung: $\quad$ al-Ma'arif, 1971

Mohammad Tahir Haji Mohammad, Rights and Duties in Syariah and Common Law, Kuala Lumpur, Ilmiah Publishers, 2003

Muhammad Ali al-Shabuni, 1999, Tafsir Ayat al-Ahkam min al-Qur'an, Beirut: Daar al-Kutub al-'Ilmiyyah

Novita Kusumaningrum, 2015, Perkawinan di bawah umur dan akibatnya (Studi putusan perceraian pasangan bawah umur Pengadilan Agama Surakarta dan Pengadilan Agama Karang Anyar) 
Fakultas Hukum Universitas Muhammadiyah surakarta

Said Agil Husin al-Munawwar, 2003, Agenda Generasi Intelektual: Ikbtiar Membangun Masyarakat Madani, Jakarta: Pena Madani

Santy Devi, P, 2012, Perkawinan Usia Dini: Kajian Sosiologis tentang Struktur Sosial di Desa Pongotan Kabupaten Bangli, Jurnal Ilmiah Sosiologi, Vol.1 No.1

Suhadi, 2012, Pernikahan Dini, Perceraian dan Pernikahan Ulang: Sebuah Telaah Dalam Perspektif Sosiologi, Jurnal Komunitas 4 (2) (2012): 168-177

Pipin Syarifin dan Zarkasy Chumaidy, 1998, Pengantar Ilmu Hukum, Bandung: Pustaka Setia,

United Nations Children's Fund, 2014,Ending Child Marriage: Progress and prospects. New York: UNICEF.

Widia Fithri, 2013, Mau Kemana Minangkabau? Magelang: Gre Publishing 